\title{
EVALUATION OF TUBERCULOSIS PROGRAM SURVEILLANCE IN THE DEPARTMENT OF HEALTH IN BLITAR DISTRICT 2018
}

Evaluasi Surveilans Program Tuberkulosis di Wilayah Kerja Dinas Kesehatan Kabupaten Blitar Tahun 2018

\author{
Harni Utari Nennong ${ }^{1}$, Atik Choirul Hidajah ${ }^{1}$, Lucia Yovits Hendrati ${ }^{1}$ \\ ${ }^{1}$ Faculty of Public Health, Universitas Airlangga \\ harniutari2154@gmail.com
}

\section{ARTICLE INFO}

Article History:

Received:

March, 23 ${ }^{\text {th }}, 2021$

Revised:

From March, $26^{\text {th }}, 2021$

Accepted:

May, $25^{\text {th }}, 2021$

Published online:

September, $30^{\text {th }}, 2021$

\begin{abstract}
Background: Tuberculosis (TB) is one of the global diseases in SDGs. To support the TB control program, it is necessary to have TB epidemiological data that can be obtained through $T B$ epidemiological surveillance activities. Aims: Overview and evaluation of the system components and attributes of TB surveillance in the Blitar District Health Office in 2018. Methods: research in the form of descriptive with evaluation study design. The subject is an evaluation of the attributes of the TB surveillance system implemented in the Blitar District Health Office in 2018. Research respondents were the head of the disease eradication section and the TB program holder at the Blitar District Health Office. Data collection was carried out by interviewing techniques and document study by reviewing secondary data. The data and information obtained were compared with existing guidelines and theories and then presented in the form of narratives, tables, and figures. Results: Based on the results of the research on the attributes of the surveillance system, it showed that the surveillance system at the Blitar District Health Office was flexible, accessible, and responsive, high data quality, the positive predictive value that could not be measured, unmet simplicity, sensitivity, timeliness, and data stability not fulfilled. Conclusion: Based on the attributes of the TB surveillance system in the Blitar District Health Office, It still needs some improvement in terms of data collection, data analysis, availability of TB surveillance guidelines to the knowledge of officers related to TB surveillance. Keyword: Attribute Surveillance, Program TB, Tuberculosis disease
\end{abstract}

\begin{abstract}
ABSTRAK
Latar Belakang: Tuberkulosis (TB) salah satu penyakit global dalam SDGs. Menunjang keberhasilan program penanggulangan TB diperlukan adanya data epidemiologi penyakit TB yang dapat diperoleh melalui kegiatan surveilans epidemiologi TB. Tujuan: mengetahui gambaran dan evaluasi komponen system atribut surveilans TB di Dinas Kesehatan Kabupaten Blitar tahun 2018. Metode: penelitian berupa deskriptif dengan rancang studi evaluasi. Subyek merupakan evaluasi atribut sistem surveilans TB yang diterapkan di Dinas kesehatan Kabupaten Blitar pada tahun 2018. Responden penelitian adalah kepala seksi pemberantasan penyakit dan pemegang program TB di Dinas Kesehatan Kabupaten Blitar. Pengumpulan data dilakukan dengan teknik wawancara dan studi dokumen dengan mengkaji data sekunder. Data dan informasi yang diperoleh dibandingkan dengan pedoman dan teori yang ada kemudian disajikan dalam bentuk narasi, tabel, dan gambar. Hasil: Berdasarkan hasil penelitian atribut sistem surveilans diperoleh bahwa sistem surveilans di Dinas Kesehatan Kabupaten Blitar sudah fleksibiltas, aksepbilitas,dan respentatif, kualitas data yang tinggi, Nilai prediktif positif yang tidak dapat diukur, kesederhanaan yang belum terpenuhi, sensitivitas, ketepatan waktu dan stabilitas data belum terpenuhi Kesimpulan: Berdasarkan atribut sistem surveilans TB di Dinas Kesehatan Kabupaten Blitar masih belum baik pelaksanaannya dalam hal pengumpulan data, analisis data, ketersediaan pedoman surveilans TB hingga pengetahuan petugas terkait dengan surveilans $T B$.
\end{abstract}

Kata Kunci: Atribut Surveilans, Program TB, Penyakit Tuberkulosis 
Harni, et al. Evaluation of Tuberculosis Program Surveillance in the Department Of Health in Blitar District 2018

\section{INTRODUCTION}

Mycobacterium tuberculosis is the ecological agent of tuberculosis. During the phase of infection, Mycobacterium tuberculosis employs a range of effector proteins to cover the immune system (Chai, Zhang, and Liu 2018). Tuberculosis, also known as TB, is a chronic infectious disease caused by any of the three mycobacterial species with the Mycobacterium tuberculosis complex (MTC) (Napp et al. 2019).

According to WHO data in 2018, globally there were 10.04 million TB cases, including 0.5 million rifampicin-resistant $\mathrm{TB}$, 600,000 drug-resistant TB cases, and 1.5 million patients who died of tuberculosis (Chai et al. 2018; Schwoebel, 2020).

The TB cases estimation in sub-Saharan Africa rises to 5 out of 10 active TB cases. South Africa is among the countries with the highest burden of TB which is the leading cause of death (Ajudua and Mash 2020).

Tuberculosis continues to be endemic in many parts of the world, including in India, clinical assessment, testament, contact tracing, diagnosis confirmation with supervised or insupervised treatment regimens for the effectiveness of eradication (Jain et al. 2020).

Tuberculosis cases in Indonesia increased from 2014 to 2018 with 566.623 cases reported. The cases were recorded in the most populated province, including West Java, East Java, and Central Java. The indicators and targets in controlling tuberculosis in Indonesia are regulated in Regulation of the Minister of Health Number 67 of 2016 on Tuberculosis Control. The targets are TB elimination by 2013 and Indonesia free of tuberculosis by 2050 (The Ministry of Health, 2018).

In 2018, there were 54\% cases of tuberculosis found in Blitar Regency. The new finding of the tuberculosis case in Blitar was yet to achieve the target, which was $70 \%$. Tuberculosis control strategies in Blitar were carried out by strengthening the surveillance system of tuberculosis (Surabaya Health Office, 2017).

Surveillance provides essential information in decision making hence the right intervention can be taken to control and prevent the health problems (Siti Malikhatin, 2017).

The tuberculosis case data is mostly undiagnosed. Implementing data analysis with demographic surveillance of TB registrations can identify undiagnosed cases. The implementation and evaluation of the TB surveillance program were enhanced in Blantyre, Malawi, where nearly one out of five adults were TB and HIV positive (MacPherson et al. 2019). The feasible and efficient surveillance system explains the dynamics of MDR-TB transmission in a country (Tagliani et al. 2021).

Tuberculosis surveillance is one of the oldest disease surveillance systems in the world. Surveillance of tuberculosis globally was aimed to assess the progress of TB control in the context of commitments and strategies that refer to the End TB strategy purposes which aim at tuberculosis elimination (Schwoebel, 2020).

The monitoring process of $\mathrm{TB}$ patients remains an issue in the era of social distancing and self-isolation. Several strategies have been implemented, including the utilization of outreach services to reach TB patients and the delivery of TB medications (Jain et al. 2020).

Active and passive evaluation of surveillance systems is necessary to ensure that the health problems are monitored effectively and efficiently. Evaluation is also essential to provide recommendations to improve the quality, efficiency, and usefulness of the surveillance per se. The objections of this study were to describe and evaluate the surveillance system based on the attributes of the surveillance system in Blitar Health Office.

\section{METHOD}

This recent research was descriptive research with an evaluation study design. The subject of the study was the tuberculosis surveillance system attributes. The research respondents were the Head of the Infectious Disease Section of the Blitar Health Office, the Deputy Supervisor of TB of the Blitar Health Office, and the Person in Charge (PIC) of TB program at Public Health Office (PHC) across Blitar Regency which consisted of 23 PHCs targeting all types of TB-related report data. This research was conducted between April to June 2019.

This study used secondary data. The data collection methods were carried out by interview using a questionnaire, observation using an observation sheet, and documentation. The variables studied were simplicity, flexibility, acceptability, sensitivity, Positive 
Harni, et al. Evaluation of Tuberculosis Program Surveillance in the Department Of Health in Blitar District 2018

Predictive Value, representativeness, timeliness, data quality, and stability.

The simplicity of a surveillance system refers to the ease of data collection, form filling, reporting, and data analysis. Flexibility is best assessed by how a system adjusts with changes without any addition in resources whether human, time, and funds.

Acceptability reflects the willingness of a party both inside and outside the system to participate in the implementation of the surveillance system. Sensitivity refers to the proportion of cases detected by a system and its ability to detect an outbreak. Positive Predictive Value is the proportion of TB cases detected by the surveillance system which actually do have the condition under surveillance.

Representativeness is assessed by the accuracy of reported events based on the person, place, and time. Timeliness reflects the speed or delay between steps in a surveillance system. Data quality assessment including the completeness of total report and the completeness of TB surveillance data, the absence of blank answers, and accuracy in reporting.

Stability is the ability of a surveillance system to provide reliable data and to maintain the availability of data. The system's ability to maintain the availability of data and information obtained compared to existing guidelines and theory. The result will be presented in the form of narration, table, and figures.

\section{RESULT}

Surveillance system evaluation in Blitar Health Office based on surveillance attributes were including the following.

\section{Simplicity}

The indicators to assess simplicity were diagnosis enforcement, the availability of personnel and infrastructures, data collection and reporting flow, and the use of laboratories. Based on the description (Table 1), it can be concluded that the result of the simplicity assessment in the TB surveillance implementation at the Blitar Health Office was perceived to be not simple.

Table 1. The Simplicity of TB Surveillance in Blitar Health Office

\begin{tabular}{lrll}
\hline Criteria & Result & Classification \\
\hline Diagnosis enforcement & $\begin{array}{l}\text { The diagnosis enforcement was perceived as easy as } \\
\text { the examined clinical symptom for tuberculosis is } \\
\text { coughing for two or more weeks. }\end{array}$ & Simple \\
\hline $\begin{array}{l}\text { The availability } \\
\text { personnel } \\
\text { infrastructures }\end{array}$ & $\begin{array}{l}\text { The staff in TB program management remain } \\
\text { insufficient. }\end{array}$ & $\begin{array}{l}\text { Complicated/Not } \\
\text { simple }\end{array}$ \\
\hline $\begin{array}{l}\text { Data collection } \\
\text { reporting flow }\end{array}$ & and & Easy & $\begin{array}{l}\text { Complicated/Not } \\
\text { simple }\end{array}$ \\
\hline $\begin{array}{l}\text { The use of laboratories } \\
\text { Complicated/Not } \\
\text { simple }\end{array}$ \\
\hline
\end{tabular}

According to the result of the interview and observation to the surveillance personnel at 23 PHCs in Blitar Regency, it is obtained that the diagnosis establishment of TB was perceived as easy as the examined clinical symptoms for tuberculosis is coughing for two or more weeks. The availability of personnel at 23 PHCs in Blitar Regency remained insufficient due to the high workload of TB personnel at PHCs across Blitar Regency, hence it was classified to be not simple.

Based on the explanation above, it can be concluded that the assessment result of the simplicity variable in the implementation of TB surveillance in the Blitar Health Office work area was not simple.

\section{Flexibility}

The result of the interview with the personnel of the TB program at PHC showed that nearly all PHCs stated that the use of the Integrated Tuberculosis Information System (SITT) in the implementation of TB surveillance was flexible. 
Table 2. The Flexibility of TB Surveillance in Blitar Health Office

\begin{tabular}{|c|c|c|}
\hline Criteria & Result & Classification \\
\hline $\begin{array}{l}\text { The implementation of } \\
\text { the Integrated }\end{array}$ & No additional fund, staff, and time & Flexible \\
\hline $\begin{array}{l}\text { Tuberculosis } \\
\text { Information } \quad \text { System } \\
\text { (SITT) }\end{array}$ & & \\
\hline $\begin{array}{l}\text { The implementation of } \\
\text { TB-HIV case finding }\end{array}$ & $\begin{array}{l}\text { There was an additional need for reagent procurement } \\
\text { funding and additional time for inspection }\end{array}$ & Inflexible \\
\hline $\begin{array}{l}\text { The flexibility of } \\
\text { ogram if it meets the ex } \\
\text { ich as the ability of a sur }\end{array}$ & $\begin{array}{ll}\text { TB surveillance } & \text { additional staff and time in } \\
\text { ting requirements, } & \text { HIV case finding. } \\
\text { illance program to } & \text { Acceptability }\end{array}$ & carrying out $\mathrm{T}$ \\
\hline
\end{tabular}
information changes without any rising costs. The interview result with the PIC of TB program at all PHCs showed that there was no additional cost in carrying out TB-HIV case finding.

This is because all reagents have been provided by the Blitar Health Office. Furthermore, almost all TB program managers at the PHCs also felt that they did not need

The indicators to assess the acceptability is the patient's willingness to be tested for TB, the willingness of Drug-Taking Supervisors (PMO), the willingness to collect the data, to disseminate the information, to give feedback. The acceptability (Table 3) is based on the interview result with the Head of the Infectious Disease Section and the Deputy Supervisor in Blitar Health Office.

Table 3. The Acceptability of TB Surveillance in Blitar Health Office

\begin{tabular}{llll}
\hline Criteria & \multicolumn{1}{l}{ Result } & Classification \\
\hline TB testing & Unwilling & Unacceptable \\
\hline $\begin{array}{l}\text { Drug-Taking } \\
\text { (PMO) }\end{array}$ & Supervisor & Willing & Acceptable \\
\hline $\begin{array}{l}\text { Participated } \\
\text { collection }\end{array}$ & in data & Willing & Acceptable \\
\hline $\begin{array}{l}\text { Participation in information } \\
\text { dissemination }\end{array}$ & Willing & Acceptable \\
\hline $\begin{array}{l}\text { Participation in giving } \\
\text { feedback }\end{array}$ & $\begin{array}{l}\text { The feedback only provided every 6 months and } \\
\text { the attendance is done through social media } \\
\text { (WhatsApp) }\end{array}$ & Unacceptable \\
\hline
\end{tabular}

According to the interview result with the TB program officer at PHCs across Blitar meet the acceptability category of TB examination criteria, nearly all PHC officers stated that people who had TB symptoms and had household contacts with TB patients were willing to check themselves at the PHC.

All family members who were appointed as PMOs were willing to supervise the drugs taking for their TB patient family members. All PHCs in Blitar Regency was always willing to conduct data collection.

\section{Sensitivity}

Based on the interview result with the Head of the Infectious Disease Section and the Deputy Supervisor in Blitar Health Office, it showed that they were always processed the obtained data from the PHC regularly every three months. However, sometimes there were some delays in sending the reports, which hindered the data processing causing the result of regularly processed data did not show the actual number of cases.

TB program officers at the PHC across Blitar Regency stated that as many as 5 PHCs did not regularly carry out data processing, while as many as 18 PHCs were always conducted data processing quarterly. Apart from data processing on a quarterly basis, the program manager at the PHC also stated that data processing was performed routinely every month for the officer performance evaluation purpose by the head of PHC which is usually organized in a mini-workshop activity at the PHC.

Based on the explanation above, it can be concluded that the result of sensitivity assessment in the implementation of TB surveillance in Blitar Health Office was insensitive. 
Harni, et al. Evaluation of Tuberculosis Program Surveillance in the Department Of Health in Blitar District 2018

\section{Representativeness}

According to the interview and observation result with the Head of the Infectious Disease Section and the Deputy Supervisor in Blitar Health Office, it reported that the TB data have been processed and analyzed based on the person, place, and time. Thus, it can be concluded that the representativeness assessment result in the implementation of TB surveillance in Blitar Health Office was representative.

\section{Timeliness}

According to the interview and observation result with the Head of the Infectious Disease Section and the Deputy Supervisor in Blitar Health Office, it showed

Table 4. The Timeliness of TB Surveillance in Blitar Health Office

\begin{tabular}{|c|c|c|}
\hline Criteria & Result & Classification \\
\hline $\begin{array}{l}\text { Case finding from the } \\
\text { reporting unit }\end{array}$ & $\begin{array}{l}\text { There were still reporting units that report the data } \\
\text { not in a regular way (more than } 3 \text { months) and the } \\
\text { case finding was only } 62.08 \%\end{array}$ & Untimely \\
\hline $\begin{array}{l}\text { Data analysis } \\
\text { interpretation }\end{array}$ & Were always carried out every 3 months & Timely \\
\hline $\begin{array}{l}\text { Information } \\
\text { dissemination } \\
\text { feedback }\end{array}$ & $\begin{array}{l}\text { Information dissemination was carried out every } 3 \\
\text { months and the monitoring evaluation feedback was } \\
\text { only carried out } 2 \text { times a year or every } 6 \text { months }\end{array}$ & Untimely \\
\hline
\end{tabular}

\section{Data Quality}

Based on the interview result with the Head of the Infectious Disease Section and the Deputy Supervisor in Blitar Health Office, there was no data absence in the report format at SITT. This was because the SITT program would not process the collected and processed data if the data were double or incomplete. Based on the description above, the quality of TB surveillance data in the Blitar Regency Health Office was of high quality.

\section{Positive Predictive Value}

Positive predictive value was the ability to identify real cases by a surveillance system compared to the gold standard and the results are also positive. A good surveillance system has the ability to detect cases that actually do have the condition under surveillance. Based on the interview result with the Head of the Infectious Disease Section and the Deputy Supervisor in Blitar Health Office, it showed that the Positive Predictive Value was not carried out in Blitar Regency Health Office.

\section{Data Stability}

The stability of a surveillance system indicator is its ability to maintain the availability of data. Based on the interview result with the Head of the Infectious Disease that not every PHC in Blitar Regency did report their case finding exactly every three months, it proved by the evidence of the accuracy of the report which only reached $30 \%$. The case finding in Blitar was still below the national standard, which was only $62.08 \%$ (Table 4). Data analysis and interpretation were always conducted every three months, however the delays in data collection by the PHC made it difficult to conduct a routine data analysis and interpretation. The dissemination of information was always carried out every three months through the SITT software, but the delays made the information did not describe the actual number of cases.
Section and the Deputy Supervisor in Blitar Health Office, it showed that the data collection and processing with SITT system can be used at any time to process data and it provided information about the TB eradication program in Blitar Regency at any time.

However, the system sometimes gets errors at least 1 time and the system repairmen also take a long time. The system repair usually requires 1 week, on average. According to the interview result with the PIC of TB program at the PHC stated the SITT system was always can be used at any time to process and to provide information about TB eradication in Blitar Regency.

There were 23 PHCs in Blitar Regency. Almost all PHCs have experienced problems in using the SITT program and there was only 1 PHC that had never experienced any problems in using the SITT system. The SITT program repairmen at the PHC took more than 24 hours of time or 1 week on average. Based on the description above, the stability of the data at the Blitar Health Office remained low, as there were still errors in the system and repairmen that took more than 24 hours of time. 
Harni, et al. Evaluation of Tuberculosis Program Surveillance in the Department Of Health in Blitar District 2018

\section{DISCUSSION}

Surveillance system evaluation based on the attributes of surveillance, in terms of simplicity of establishing a TB diagnosis was relatively easy. The availability of facilities and infrastructures at the Blitar Health Office was sufficient as it was equipped with computers, communication tools, TB implementation guidelines, and some vehicles to implement the program. The availability of personnel at the Blitar Health Office was inadequate due to the high workload of the PIC of the TB program. A similar study carried out by (Mlotshwa et al. 2017) showed that the simplicity, flexibility, stability attribute, contribute to achieve the objectives, and inform the TB control program in Eden City. Reporting flow using SITT software has been integrated directly with the PHC, District/City Health Office, Province Health Office, and the Ministry of Health. It was in line with research conducted by (Kiazyk and Ball, 2017).

The flexibility attribute in the implementation of SITT has been flexible as there was no additional cost, staff, and time required. A research carried out by (Majerovich, Fernandes, and Varia 2017) reported that the risk factor data accuracy in integrated Public Health Information System (iPHIS) was relevant from a cost-benefit perspective because the resource could be mobilized to follow up latent tuberculosis infection (LTBI) cases that were at increased risk to become active TB cases (e.g. due to a medical risk factor).

The acceptability attribute to improve public awareness and willingness to be tested for TB was still lacking due to inadequate participation from the officers in promoting to the community as well as contacts and TB patients as an implementation of the Directly Observed Treatment of Short Course (DOTS) program, which is the case finding with a passive promotion case detection. All PHC officers stated that people who had TB symptoms and had household contact with TB patients were willing to check themselves at the PHC. The data collection in TB surveillance using a computerized system of SITT software. This study had a similar result to a research by (Kiazyk and Ball 2017) which showed that the funding requirements and monitoring tools were complete and the TB program staff have been reported high

acceptance of the national MDR-TB surveillance introduction.

The sensitivity attribute of the implementation of TB surveillance in Blitar Health Office was insensitive as it processed the data on a quarterly basis. This result was in line with the research by (Chaintarli et al. 2018) which stated that there was no increase in sensitivity applied in the TB surveillance system.

Representativeness attribute assessment in the implementation of TB surveillance in Blitar Health Office was representative, a similar study was also conducted by (Iskandar, Airport, and Aceh 2019).

The attribute of timeliness in case finding and reporting has not been timely. This study had a similar result to a research by (Rivière et al. 2017), dissemination of information was always carried out every 3 months through SITT software, however due to delays in data collection by the PHCs, the results of the information sometimes did not reflect the actual number of cases.

The data quality in TB surveillance in the Blitar Regency Health Office work area was high as there was no data absence. No data absence was due to the reporting system used the same research system, which was the SITT system (Green et al. 2019). The use of the SITT system does not allow the user to not fill in all the available formats as the system will not process if there is data missing in the format.

\section{CONCLUSION}

The conclusions on the evaluation of the tuberculosis surveillance system at the Blitar Regency Health Office based on the attribute components are the following.

1. The assessment result of the simplicity variable in the implementation of $\mathrm{TB}$ surveillance at the Blitar Health Office, based on the availability of staff and infrastructures, data collection and reporting flow, and the use of laboratory, was not simple.

2. The flexibility of tuberculosis surveillance system evaluation at the Blitar Health Office, based on the implementation of SITT, was flexible.

3. The acceptability of tuberculosis surveillance system evaluation at the Blitar Health Office, based on the willingness of Drug-Taking Supervisors (PMO), the 
Harni, et al. Evaluation of Tuberculosis Program Surveillance in the Department Of Health in Blitar District 2018

participation to collect the data, to conduct data collection, and to disseminate the information, was acceptable.

4. The sensitivity of tuberculosis surveillance system evaluation at the Blitar Health Office, based on the data delay reported by PHC resulting the information did not reflect the actual number of cases, it can be concluded that it was not sensitive yet.

5. The representativeness assessment result in the implementation of TB surveillance in Blitar Health Office was representative, assessed by data processing and analyzing based on the person, place, and time.

6. The timeliness of tuberculosis surveillance system evaluation in Blitar Health Office was untimely, assessed based on case finding from the reporting unit, the information dissemination, and providing feedback.

7. The data quality of tuberculosis surveillance system evaluation in Blitar Health Office was good, as seen from the data processing criteria through an integrated-computerized system.

8. The data stability of tuberculosis surveillance system evaluation in Blitar Health Office was unstable, as seen from the system that often gets errors and the repairmen take a long time.

\section{SUGGESTION}

1. Strengthen commitment and cooperation as we all maintain good communication between District/City Health Office and the province officers to improve the timeliness and completeness of reports in the surveillance system.

2. Perform the data collection, data analysis, provide recommendations and feedback following the Standard Operating Procedures (SOP) in a timely way.

3. Conduct monitoring and directing PHCs that still have problems in reporting $\mathrm{TB}$ surveillance.

4. The Health Office is expected to improve data stability.

\section{ACKNOWLEDGEMENT}

The researchers would like to acknowledge the help of the Blitar Regency Health Office, the Head of Disease Control, the Head of the Infectious Disease Section, and the Person in Charge (PIC) of the TB program.

\section{REFERENCES}

Ajudua, Febisola I., and Robert J. Mash. 2020. "Implementing Active Surveillance for TB-The Views of Managers in a Resource Limited Setting, South Africa." PLoS ONE 15(10 October):1-15. doi: 10.1371/journal.pone.0239430.

Chai, Qiyao, Yong Zhang, and Cui Hua Liu. 2018. "Mycobacterium Tuberculosis: An Adaptable Pathogen Associated with Multiple Human Diseases." Frontiers in Cellular and Infection Microbiology 8(MAY):1-15. doi: 10.3389/fcimb.2018.00158.

Chaintarli, K., S. Jackson, S. Cotter, and J. O'Donnell. 2018. "Evaluation and Comparison of the National Tuberculosis (TB) Surveillance System in Ireland before and after the Introduction of the Computerised Electronic Reporting System (CIDR)." Epidemiology and Infection 146(14):1756-62. doi: $10.1017 /$ S0950268818001796.

Dinas Kesehatan Kota Surabaya. 2017. "Profil Dinas Kesehatan Kota Surabaya." Dinas Kesehatan 163.

Green, Ridgely Fisk, Mary Ari, Katherine Kolor, W. David Dotson, Scott Bowen, Nancy Habarta, Juan L. Rodriguez, Lisa C. Richardson, and Muin J. Khoury. 2019. "Evaluating the Role of Public Health in Implementation of GenomicsRelated Recommendations: A Case Study of Hereditary Cancers Using the CDC Science Impact Framework." Genetics in Medicine 21(1):28-37. doi: 10.1038/s41436-018-0028-2.

Iskandar, Sultan, Muda Airport, and Banda Aceh. 2019. "Implementation of Epidemiology Surveillance Based on Attribute Of." 3214:155-62. doi: 10.21276/sjbr.2019.4.4.7.

Jain, Vijay Kumar, Karthikeyan P. Iyengar, David Ananth Samy, and Raju Vaishya. 2020. "Tuberculosis in the Era of COVID-19 in India." Diabetes and Metabolic Syndrome: Clinical Research and Reviews 14(5):1439-43. doi: 10.1016/j.dsx.2020.07.034.

Kemenkes RI. 2018. "Tuberkulosis ( TB )." Tuberkulosis 1(april):2018.

Kiazyk, S., and TB Ball. 2017. "Latent Tuberculosis Infection: An Overview." Canada Communicable Disease Report 43(3/4):62-66. 
Harni, et al. Evaluation of Tuberculosis Program Surveillance in the Department Of Health in Blitar District 2018

10.14745/ccdr.v43i34a01.

MacPherson, Peter, McEwen Khundi, Marriott Nliwasa, Augustine T. Choko, Vincent K. Phiri, Emily L. Webb, Peter J. Dodd, Ted Cohen, Rebecca Harris, and Elizabeth L. Corbett. 2019. "Disparities in Access to Diagnosis and Care in Blantyre, Malawi, Identified through Enhanced Tuberculosis Surveillance and Spatial Analysis." BMC Medicine 17(1):1-11. doi: 10.1186/s12916-019$1260-6$.

Majerovich, JA, L. Fernandes, and M. Varia. 2017. "Evaluation of Latent Tuberculosis Infection Surveillance in Peel Region, Ontario, 2010-2014." Canada Communicable Disease Report 43(5):114-18. doi: 10.14745/ccdr.v43i05a06.

Mlotshwa, Mandla, Sandra Smit, Seymour Williams, Carl Reddy, and Andrew Medina-Marino. 2017. "Evaluating the Electronic Tuberculosis Register Surveillance System in Eden District, Western Cape, South Africa, 2015." Global Health Action 10(1). doi: 10.1080/16549716.2017.1360560.

Napp, Sebastian, Giovanna Ciaravino, Bernat Pérez de Val, Jordi Casal, José Luis Saéz, and Ana Alba. 2019. "Evaluation of the Effectiveness of the Surveillance System for Tuberculosis in Cattle in Spain." Preventive Veterinary Medicine 173(September): 104805 . doi: 10.1016/j.prevetmed.2019.104805.

Rivière, Julie, Yann Le Strat, Pascal Hendrikx, and Barbara Dufour. 2017. "CostEffectiveness Evaluation of Bovine Tuberculosis Surveillance in Wildlife in France (Sylvatub System) Using Scenario Trees." PLOS ONE 12(8). doi: 10.1371/journal.pone.0183126.

Schwoebel, Valérie. 2020. "Surveillance of Tuberculosis." Indian Journal of Tuberculosis 67(4):S33-42. doi: 10.1016/j.ijtb.2020.11.006.

Siti Malikhatin, Lucia Yovita Hendrat. 2017. "KUALITAS SISTEM SURVEILANS PES KABUPATEN PASURUAN TAHUN 2014 BERDASARKAN PENILAIAN ATRIBUT SISTEM SURVEILANS." (December 2016):6074. doi: 10.20473/jbe.v5i1.

Tagliani, Elisa, Richard Anthony, Thomas A. Kohl, Albert De Neeling, Vlad
Nikolayevskyy, Csaba Ködmön, Florian P. Maurer, Stefan Niemann, Dick Van Soolingen, Marieke J. Van Der Werf, and Daniela Maria Cirillo. 2021. "Use of a Whole Genome Sequencingbased Approach for Mycobacterium Tuberculosis Surveillance in Europe in 2017-2019: An ECDC Pilot Study." European Respiratory Journal 57(1). doi: 10.1183/13993003.02272-2020. 